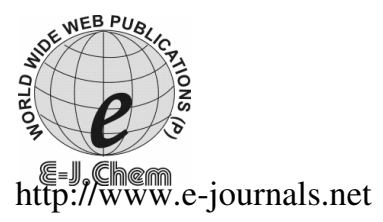

ISSN: 0973-4945; CODEN ECJHAO

E-Journal of Chemistry

2011, 8(1), 373-385

\title{
Kinetics and Equilibrium Studies on the Sorption of Manganese(II) and Nickel(II) onto Kaolinite and Bentonite
}

\author{
B. SATHYANARAYANA and K.SESHAIAH* \\ Department of Chemistry \\ S.G.S.A. College, S.V. University, Tirupati-517502, India \\ *Department of Chemistry \\ S.V. University, Tirupati -517 502, India \\ seshaiahsvu@gmail.com
}

Received 10 April 2010; Accepted 22 May 2010

\begin{abstract}
The sorption of manganese(II) and nickel(II) onto two adsorbents, kaolinite and bentonite from aqueous solution was studied in batch mode. Effect of $\mathrm{pH}$, contact time, adsorbent dose, and initial metal ion concentration on adsorption was investigated. The adsorbents exhibit good sorption potential for manganese(II) and nickel(II) with a peak value at $\mathrm{pH} 5$ and $\mathrm{pH} 6$ respectively. More than $70 \%$ sorption occurred within $20 \mathrm{~min}$ for manganese(II) and nickel(II) and equilibrium was attained at $90 \mathrm{~min}$. for manganese(II) and $120 \mathrm{~min}$ for nickel(II). Freundlich and Langmuir's mathematical models were used to describe batch adsorption. The adsorption was found to be favourable with respect to both the isotherms. The adsorption of the two metal ions from aqueous solution onto two adsorbents followed pseudo-second order kinetics.
\end{abstract}

Keywords: Adsorption, Heavy metal ions, Kaolinite, Bentonite.

\section{Introduction}

Heavy metals enter into the environment through natural phenomena like volcanoic eruptions, weathering, weathering of rocks and human activities such as industrial activities, agricultural practices, transport and waste disposal. These heavy metals are necessary in small amount for normal development of the biological cycles but they become toxic at high concentration $^{1}$. The removal of heavy metals from aqueous solution has received a considerable attention in recent years because these heavy metals in the waste water can be readily adsorbed by aquatic animals and directly enter the human food chain (bioamplification), thus causing a high health risk to the consumers. Hence these heavy metals should be removed from waste water before discharging into natural water bodies. Numbers of methods are available for the removal of heavy metal ions from aqueous solutions. 
These methods include ion-exchange, electrodialysis, precipitation, solvent extraction, reverse osmosis, electrodepositing, adsorption ${ }^{2-7}$. Among these methods, adsorption method appears to be an attractive method due to its efficiency and the ease with which it can be applied in the treatment of heavy metals containing wastewater ${ }^{8}$. In order to minimize processing costs, low cost adsorbents have been used by the several recent investigators. Clay minerals like kaolinite and bentonite are the readily available low cost adsorbents and offer a cost-effective, alternative to conventional treatment of industrial wastewater ${ }^{9}$. Ionexchange and adsorption mechanism of clay minerals are utilized to remove heavy metals from waste water. In the present study the low cost adsorbents namely kaolinite and bentonite were used for the removal of manganese(II) and nickel(II) from wastewater. The effect of various parameters like $\mathrm{pH}$, adsorbent dose, contact time, initial metal ion concentration on the removal of these metals have been investigated.

\section{Experimental}

The bentonite and kaolinite employed as adsorbents in the present study were obtained from Indian Petrochemicals Limited, Vadodara, India. The mineralogical composition, granulometry of the two adsorbents are shown in the Table 1.

Table 1. Chemical composition ${ }^{*}$ and granulometry of kaolinite and bentonite

\begin{tabular}{lcc}
\hline \multirow{2}{*}{ Constituents } & \multicolumn{2}{c}{ Adsorbents } \\
\cline { 2 - 3 } & Kaolinite & Bentonite \\
\hline $\mathrm{SiO}_{2}$ & 44.2 & 44 \\
$\mathrm{Al}_{2} \mathrm{O}_{3}$ & 39.7 & 16 \\
$\mathrm{TiO}_{2}$ & 1.39 & 1 \\
$\mathrm{Fe}_{2} \mathrm{O}_{3}$ & 0.13 & 12.5 \\
$\mathrm{MgO}$ & 0.03 & 2.4 \\
$\mathrm{CaO}$ & - & 2.6 \\
$\mathrm{MnO}$ & 0.002 & - \\
$\mathrm{Na}$ & 0.013 & 2.2 \\
$\mathrm{~K}_{2} \mathrm{O}$ & 0.050 & - \\
$\mathrm{F}$ & 0.013 & - \\
$\mathrm{P}_{2} \mathrm{O}_{5}$ & 0.034 & - \\
$\mathrm{Particle} \mathrm{size,} \mu \mathrm{m}$ & 8 & 70 \\
Surface area, $\mathrm{m}^{2} / \mathrm{g}$ & 20.67 & 49.34 \\
\hline \multicolumn{2}{c}{$*$ All values are in $\%$ byeight }
\end{tabular}

* All values are in \% by weight

All reagents used were of analytical grade and deionised double distilled (DDD) water was used throughout the experimental studies. $\mathrm{HCl}, \mathrm{NaOH}$ and buffer solutions procured from E.merk, were used to adjust $\mathrm{pH}$. Analytical reagent grade $\mathrm{MnSO}_{4}, 4 \mathrm{H}_{2} \mathrm{O}$ and $\mathrm{NiSO}_{4}$, $7 \mathrm{H}_{2} \mathrm{O}$ were used for preparing stock solutions.

\section{Preparation of stock solutions}

Stock solutions (1000 mg/L) of $\mathrm{Mn}$ (II) and $\mathrm{Ni}(\mathrm{II})$ were prepared by dissolving $\mathrm{MnSO}_{4} 4 \mathrm{H}_{2} \mathrm{O}$ and $\mathrm{NiSO}_{4} 7 \mathrm{H}_{2} \mathrm{O}$ in deionised double-distilled water respectively. Working standards were prepared by progressive dilution of stock metal solutions using deionized doubled distilled water.

An Elico (Li-129) $\mathrm{pH}$ meter was used for $\mathrm{pH}$ measurements in the present study. An atomic absorption spectrophotometer (Varion Spectra 55 Austraila) with single element hallow cathode lamps of respective elements operating with an air-acetylene flame was used for the determination of metal ion concentration in solutions. 


\section{Batch mode adsorption studies}

In the present investigation, batch mode operation was selected in order to measure the progress of adsorption. Batch equilibrium tests were conducted at constant temperature $30 \pm 1{ }^{\circ} \mathrm{C}$ using mechanical shaker. The effect of various parameters such as $\mathrm{pH}$, contact time, adsorbent dose and initial metal ion concentration was studied. For each experimental run, $100 \mathrm{~mL}$ metal solution of known concentration was taken in a $250 \mathrm{~mL}$ stoppered reagent bottle, $\mathrm{pH}$ was adjusted to the required value and a known amount of the kaolinite or bentonite was introduced. The mixture was agitated at room temperature $\left(30 \pm 1{ }^{\circ} \mathrm{C}\right)$ using a mechanical shaker (macro scientific works Delhi, India) at a constant rate of $150 \mathrm{rpm}$ for a prescribed time to attain equilibrium. After equilibration, the sorbent solution mixture was centrifuged at $20000 \mathrm{rpm}$ for $20 \mathrm{~min}$ and the supernatant was analysed for metal ion concentration using atomic absorption Spectrophotometer.

Blank solutions were treated similarly (without adsorbent) and then recorded concentration by the end of each operation was taken as initial one. To study the effect of $\mathrm{pH}$ on sorption, the $\mathrm{pH}$ of the metal ion solution was varied from 1 to 8 by the addition of $0.1 \mathrm{M} \mathrm{HCl}$ or $0.1 \mathrm{M} \mathrm{NaOH}$ prior to experiment. The effect of sorbent dosage on metal ion sorption was performed by varying the amount of sorbent from 0.5 to $3.5 \mathrm{~g}$. Kinetics and effect of contact time were studies at different time intervals over range of 20 to 130 minutes. Adsorption isotherms and effect of initial metal ion concentration were studies by varying the initial concentration from $40 \mathrm{mg} / \mathrm{L}$ to $200 \mathrm{mg} / \mathrm{L}$. All batch experiments were carried out in duplicate and the values were reported average of two readings.

\section{Sorption isotherm models}

The sorption equilibrium data of managanese(II) and nickel(II) on kaolinite and bentonite were analysed in terms of Freundlich and Langmuir isotherm models ${ }^{10}$. The relative coefficients of these models were calculated using linear least-squares fitting. The Freundlich isotherm equation $X / m=k_{F} c_{e}^{1 / n}$ can be written in the linear from as given below

$$
\log \frac{X}{m}=\log k_{F}+\frac{1}{n} \log C_{e}
$$

Where $\mathrm{X} / \mathrm{m}$ and $\mathrm{C}_{\mathrm{e}}$ are the equilibrium concentrations of manganese(II) / nickel(II) in the adsorbed and liquid phases in $\mathrm{mmol} / \mathrm{g}$ and $\mathrm{mmol} / \mathrm{L}$ respectively. $K_{F}$ and $\mathrm{n}$ are the Freundlich constants that are related to the sorption capacity and sorption intensity, respectively ${ }^{11}$. The Freundlich constants $K_{F}$ and n can be calculated from the slope and intercept of the linear plot, with $\log (X / \mathrm{m})$ vs. $\log C_{e}$.

The Langmuir sorption isotherm equation $X / m=Q_{m} k_{L} C_{e} /\left(1+k_{L} C_{e}\right)$ on linearization becomes.

$$
\frac{C_{e}}{(X / m)}=\frac{C_{e}}{Q_{m}}+\frac{1}{Q_{m} k_{L}}
$$

Where $Q_{m}$ and $k_{L}$ are Langmuir constants which are related to sorption capacity and energy of sorption respectively, can be calculated from the intercept and slope of the linear plot, $C e /(x / m)$ vs. $C_{e}$. 


\section{Kinetic models}

The sorption kinetic data of manganese(II) and nickel(II) on various adsorbents studied were analyzed in terms of pseudo-first-order and pseudo-second order sorption equations ${ }^{12}$. The pseudo-first order equation is shown below:

$$
\frac{d q_{t}}{d t}=k_{1}\left(q_{e}-q_{t}\right)
$$

Where $k_{l}\left(\mathrm{~min}^{-1}\right)$ is the rate constant of the pseudo-first-order sorption, $q_{t}(\mathrm{mg} / \mathrm{g})$ denotes, the amount of sorption at time $(\mathrm{min})$ and $q_{e}(\mathrm{mg} / \mathrm{g})$ is the amount of sorption at equilibrium. After definite integration by application of the conditions $q_{t}=0$ at $t=0 q_{t}=q_{t}$ at $t=t$ eq. (3) becomes.

$$
\log \left(q_{e}-q_{t}\right)=\log q_{e}-\frac{k_{1}}{2.303} t
$$

The sorption rate constant, $\mathrm{k}_{1}$, can be calculated by plotting $\log \left(q_{e}-q_{t}\right) v s$. $t$. The pseudo-second-order equation can be written as

$$
\frac{d q_{t}}{d t}=k_{2}\left(q_{e}-q_{t}\right)^{2}
$$

Where $k_{2}(\mathrm{~g} / \mathrm{mg} / \mathrm{min})$ is the rate constant. Integration of eq.(5) and application of the conditions $\mathrm{q}_{\mathrm{t}}=0$ at $t=0 q_{t}=q_{t}$ at $t=t$, give

$$
\frac{1}{q_{e}-q_{t}}=\frac{1}{q_{e}}+k_{2} t
$$

The following equation can be obtained on rearranging eq. (6) in to a linear from

$$
\frac{t}{q_{t}}=\frac{1}{k_{2} q_{e}^{2}}+\frac{1}{q_{e}} t
$$

$K_{2}$ and $q_{e}$ can be obtained from the intercept and slope of a plot $t / q t v s . t$.

\section{Results and Discussion}

\section{Effect of $p H$ on adsorption}

In order to optimize, the $\mathrm{pH}$ of maximum removal efficiency experiments were conducted at a wide range of $\mathrm{pH} 1$ to 8 by adding $2.5 \mathrm{~g}$ of kaolinite or bentonite adsorbents separately with $100 \mathrm{~mL}$ of $100 \mathrm{mg} / \mathrm{L}$ metal solutions at room temperature $\left(30 \pm 1{ }^{0} \mathrm{C}\right)$. The results wee included in the Tables $2 \& 3$ and are graphically represented in Figures $1 \& 2$.

Table 2. Effect of $\mathrm{pH}$ on percent removal of manganese(II)

\begin{tabular}{ccc}
\hline \multirow{2}{*}{$\mathrm{pH}$} & \multicolumn{2}{c}{ Adsorbents $^{*}$} \\
\cline { 2 - 3 } & Kaolinite & Bentonite \\
\hline 1 & 22.41 & 30.45 \\
2 & 50.08 & 60.62 \\
3 & 76.43 & 82.34 \\
4 & 84.83 & 88.12 \\
5 & 89.01 & 92.45 \\
6 & 86.2 & 90.14 \\
7 & 84.12 & 87.23 \\
8 & 82 & 85.24 \\
\hline
\end{tabular}

* All values are percent removal 
$\underline{\text { Table 3. Effect of } \mathrm{pH} \text { on percent removal of nickel(II) }}$

\begin{tabular}{ccc}
\hline \multirow{2}{*}{$\mathrm{pH}$} & \multicolumn{2}{c}{ Adsorbents* } \\
\cline { 2 - 3 } & Kaolinite & Bentonite \\
\hline 1 & 24.32 & 40.41 \\
2 & 53.21 & 75.2 \\
3 & 79.62 & 84.43 \\
4 & 85.43 & 90.12 \\
5 & 89.35 & 93.24 \\
6 & 90.21 & 95.62 \\
7 & 87.24 & 92.63 \\
8 & 78.23 & 86.03 \\
\hline
\end{tabular}

*All values are percent removal

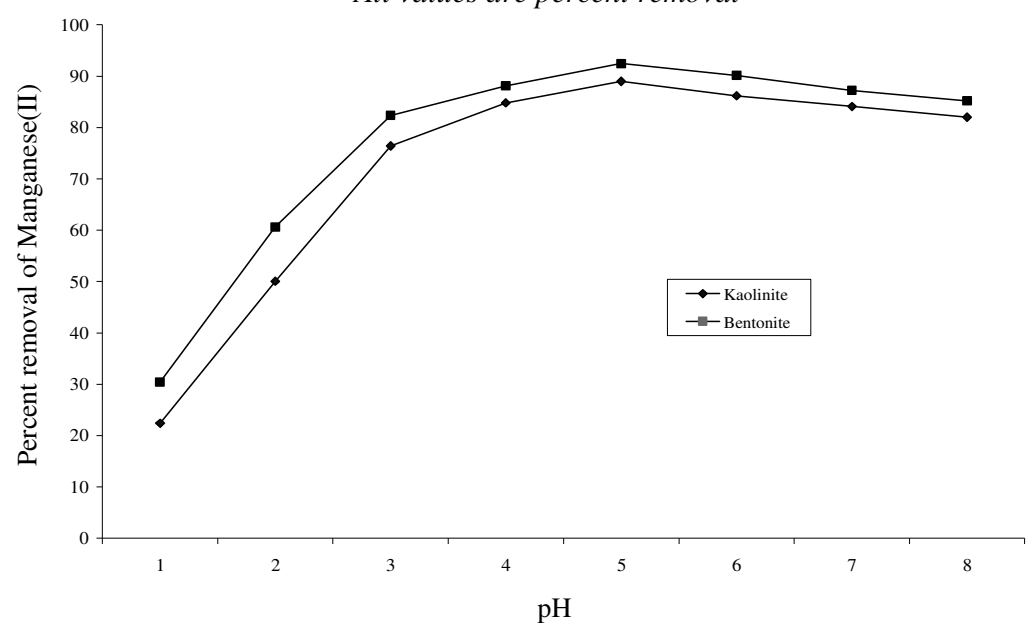

Figure 1. Effect of $\mathrm{pH}$ on percent removal of manganese(II)

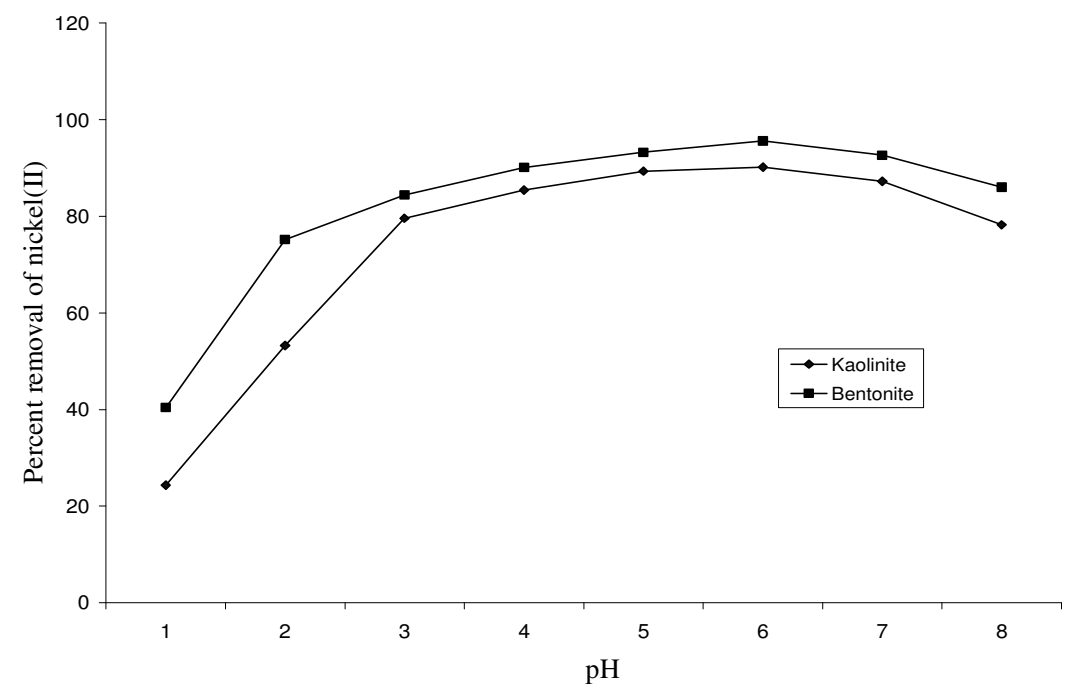

Figure 2. Effect of $\mathrm{pH}$ on percent removal of nickel(II) 
From the graphs it is clear that adsorption of manganese(II) and nickel(II) depends on $\mathrm{pH}$ of the solution. Sorption of manganese(II) and nickel(II) increased with increase in $\mathrm{pH}$ of the two adsorbents. At low pH, manganese(II) and nickel(II) sorption is very low. At low pH metal cations and protons compete for binding sites on adsorbent surface which results in lower sorptions of metal ions. It is known that mineral acids affect, the structure of kaolinite and bentonite. The extent of the damage to the structure of adsorbents depends upon $\mathrm{pH}$. The structure of kaolinite and bentonite collapse in the presence of acids, when $\mathrm{pH}$ is lower than 5; but the severity would be more at low $\mathrm{pH}$ below 3 . In fact the two adsorbents are not recommended as adsorbents at $\mathrm{pH}$ less than 5 . But both kaolinite and betonite are very stable at higher $\mathrm{pH}$. The sorption of manganese(II) on the two adsorbents reaches a maximum at $\mathrm{pH} 5$ and that of nickel(II) at $\mathrm{pH} 6$. But at higher $\mathrm{pH}$ values lower sorption is attributed due to reduced solubility of the metal ions and their precipitation as hydroxides.

\section{Effect of adsorbent dose}

The dependence of adsorption of manganese(II) and nickel(II) on the amount of kaolinite and bentonite was studied by varying the adsorbent dose from 0.5 to $3.5 \mathrm{~g}$ at room temperature $\left(30 \pm 1{ }^{\circ} \mathrm{C}\right)$ and at their optimal $\mathrm{pH}$, while keeping the volume and concentration of the metal solution constant. The results are given in Tables $4 \& 5$ and graphically represented in Figures $3 \& 4$. The figures indicate that sorption increased with increasing sorbent dose up to $2.5 \mathrm{~g}$ and than there was no further increase of sorption. It is evident that the maximum removal of manganese(II) $89.11 \%$ at $100 \mathrm{mg} / \mathrm{L}$ concentration was obtained with $2.5 \mathrm{~g}$ of kaolinite and $92.12 \%$ with $2.5 \mathrm{~g}$ of bentonite. The maximum removal of nickel(II) $90.3 \%$ at $100 \mathrm{mg} / \mathrm{L}$ concentration was obtained with $2.5 \mathrm{~g}$ of adsorbent dose of kaolinite and $95.3 \%$ with bentonite.

Table 4. Effect of adsorbent dosage on percent removal of manganese(II)

\begin{tabular}{ccc}
\hline \multirow{2}{*}{ Adsorbent dose, g. } & \multicolumn{2}{c}{ Adsorbents } \\
\cline { 2 - 3 } & Kaolinite & Bentonite \\
\hline 0.5 & 56.44 & 62.3 \\
1.0 & 69.1 & 80.28 \\
1.5 & 78.22 & 84.2 \\
2.0 & 85.15 & 90.13 \\
.2 .5 & 89.11 & 92.12 \\
3.0 & 89.11 & 92.12 \\
3.5 & 89.11 & 92.12 \\
\hline
\end{tabular}

* All values are percent removal of manganese(II)

Table 5. Effect of adsorbent dosage on percent removal of nickel(II)

\begin{tabular}{ccc}
\hline \multirow{2}{*}{ Adsorbent dose, g. } & \multicolumn{2}{c}{ Adsorbents* } \\
\cline { 2 - 3 } & Kaolinite & Bentonite \\
\hline 0.5 & 58.2 & 64.5 \\
1 & 71.28 & 82.2 \\
1.5 & 80.2 & 86.4 \\
2 & 87.12 & 94.5 \\
2.5 & 90.3 & 95.3 \\
3 & 90.3 & 95.3 \\
3.5 & 90.3 & 95.3 \\
\hline
\end{tabular}

* All values are percent removal 


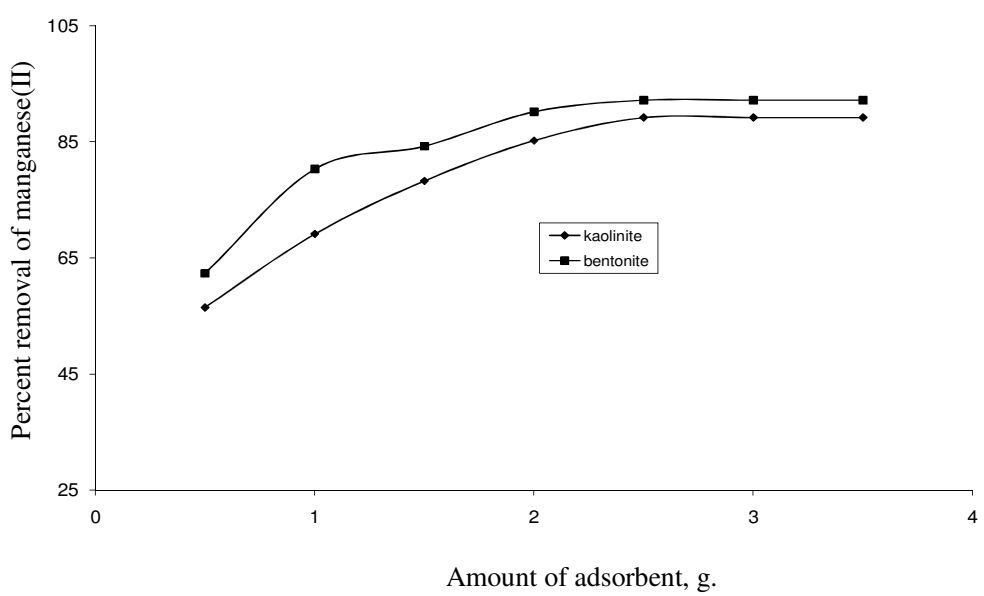

Figure 3. Effect of adsorbent dosage on percent removal of manganese (II)

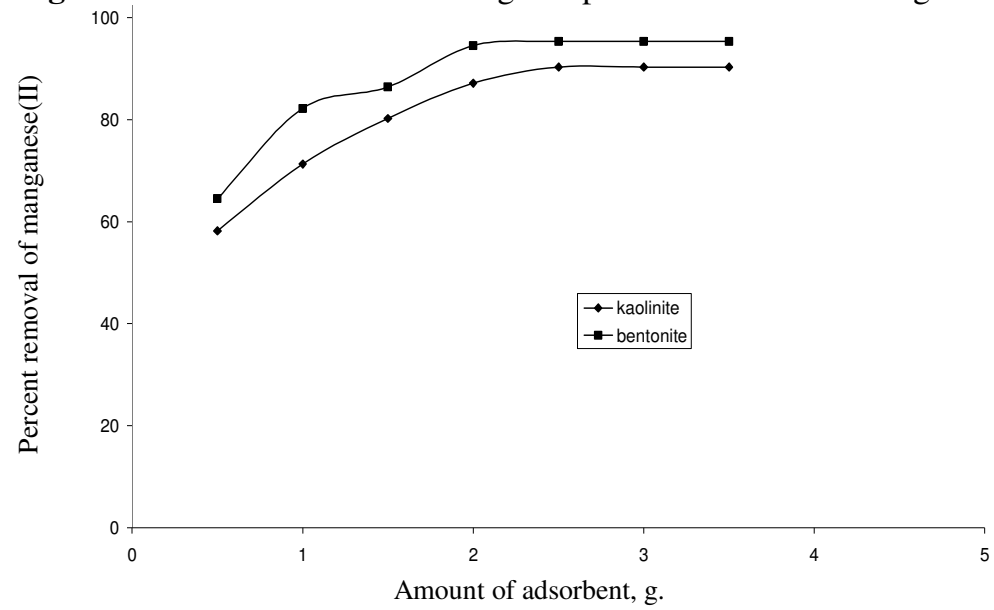

Figure 4. Effect of adsorbent dose on percent removal of manganese(II)

\section{Percent removal of manganese(II)}

The adsorption of the heavy metals increased rapidly with increase in the dose of the adsorbents due to greater availability of the exchangeable sites or surface area. Hence adsorption with manganese(II) and nickel(II) increases with increase of dose of adsorbent as the surface area increases with increase of dose of the adsorbent.

Among the two adsorbents, adsorption is more with bentonite than with kaolinite. This is because that bentonite has more surface area (surface area ranges from 600 to $800 \mathrm{~m}^{2} / \mathrm{g}$ ) and high cation exchange capacities, whereas kaolinite has low surface area (surface areas ranges from 7 to $30 \mathrm{~m}^{2} / \mathrm{g}$ ) and low cation exchange capacity.

\section{Effect of contact time}

The equilibrium time is one of the characteristics, defending efficiency in the removal of heavy metals. The effect of contact time and the percent removal of manganese(II) and nickel(II) form aqueous solution by kaolinite and bentonite is shown in the Figures $5 \& 6$ and in Tables 6 \& 7. 


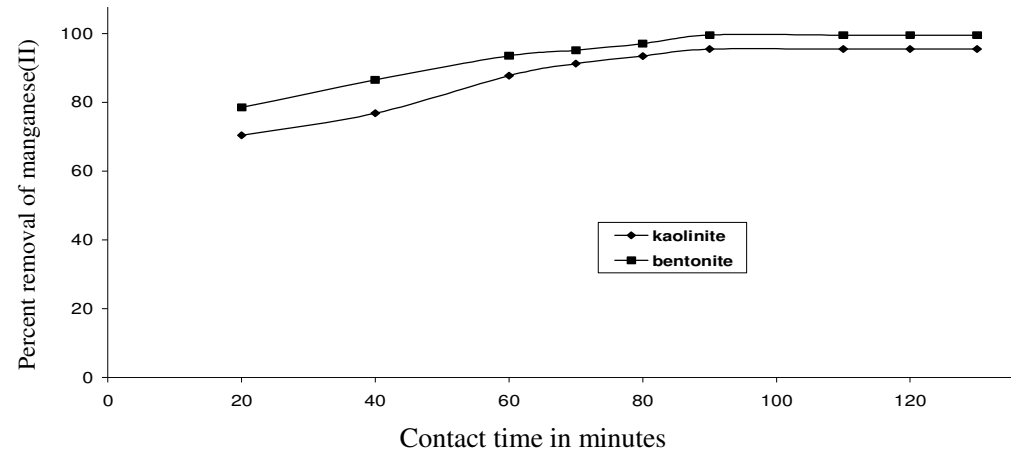

Figure 5. Effect of contact time on percent removal of manganese(II)

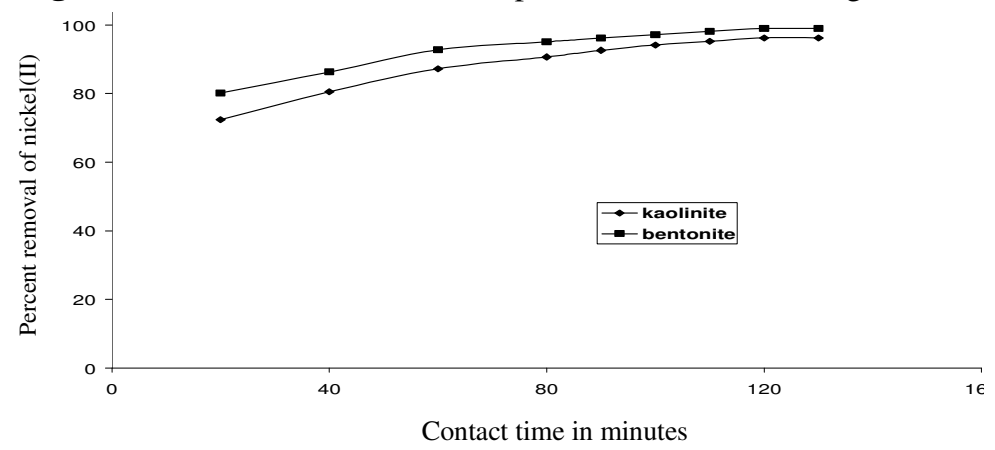

Figure 6. Effect of contact time on percent removal of nickel(II)

Table 6. Effect of contact time on percent removal of manganese(II)

\begin{tabular}{ccc}
\hline \multirow{2}{*}{ Contact time, minutes } & \multicolumn{2}{c}{ Adsorbents* } \\
\cline { 2 - 3 } & Kaolinite & Bentonite \\
\hline 20 & 70.41 & 78.5 \\
60 & 76.78 & 86.52 \\
70 & 87.73 & 93.5 \\
80 & 91.26 & 95.1 \\
90 & 93.46 & 97.02 \\
110 & 95.45 & 99.53 \\
120 & 95.45 & 99.53 \\
130 & 95.45 & 99.53 \\
*all values are percent removal & 95.45 & 99.53 \\
\hline
\end{tabular}

Table 7. Effect of contact time on percent removal of nickel(II)

\begin{tabular}{ccc}
\hline \multirow{2}{*}{ Contact time, $\min$} & \multicolumn{2}{c}{ Adsorbents" } \\
\cline { 2 - 3 } & Kaolinite & Bentonite \\
\hline 20 & 72.38 & 80.21 \\
60 & 80.57 & 86.32 \\
80 & 87.29 & 92.81 \\
90 & 90.72 & 95.12 \\
100 & 92.66 & 96.2 \\
110 & 94.21 & 97.23 \\
120 & 95.26 & 98.21 \\
130 & 96.26 & 99 \\
\multicolumn{2}{c}{ * All values are percent removal } \\
\hline
\end{tabular}


It has been observed from the above data that over $70 \%$ of the adsorption of manganese(II) form aqueous solution by kaolinite and benonite was completed with in first 20 minutes and equilibrium was reached at 90 minutes. In case of adsorption of nickel(II), over $75 \%$ of the adsorption of nickel(II) from aqueous solutions by the two adsorption was completed with in first 20 minutes and equilibrium was reached at 120 minutes. This was because of rapid diffusion of metal ions form solution to the external surface of adsorbents where the metal ions sorbs at the active surface of the two adsorption.

\section{Sorption kinetics}

The time profile and order of kinetic model for manganese(II) and nickel(II) are shown in the Figures $7 \& 8$ and in Tables $8 \& 9$.

The results indicate that the Kinetic behaviour of manganese(II) and nickel(II) on the two adsorbents follow pseudo-second order kinetics and $\mathrm{R}^{2}$ value ranged form 0.9975 to 0.9993 for manganese(II) and form 0.9994 to 0.9997 for nickel(II). Several authors, who studied sorption of divalent metals on heteragoneous sorbents, reported that the most of metal sorption kinetics follows pseudo - second order mechanism ${ }^{13}$. Compared to the pseudo-second order equation, the pseudo-first order equation shows a poor correlation with the experimental data.

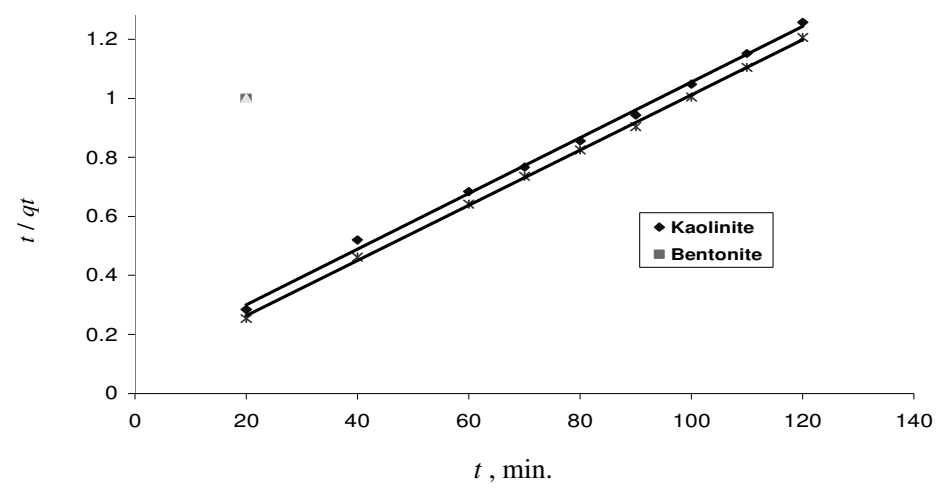

Figure 7. Time profile and pseudo second order kinetics model for manganese(II)

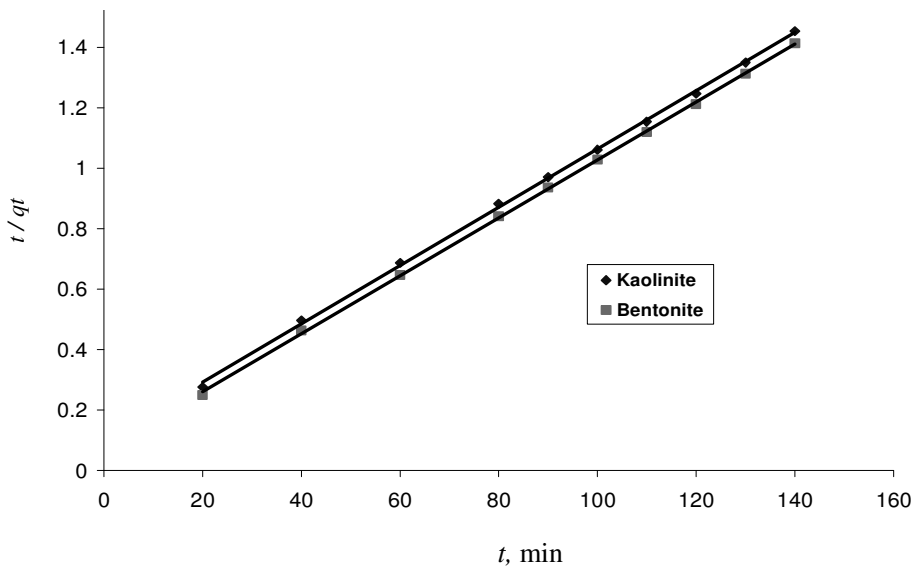

Figure 8. Time profile and pseudo second order kinetics model for nickel(II) 
Table 8. Time profile and pseudo second order kinetics model for manganese(II)

\begin{tabular}{ccc}
\hline & \multicolumn{2}{c}{ Adsorbents } \\
\cline { 2 - 3 } Time in minutes, $t$ & Kaolinite & Bentonite \\
\hline 20 & $\begin{array}{c}\text { Time/equilibrium } \\
\text { concentration at time, } t / q t\end{array}$ & $\begin{array}{c}\text { Time/equilibrium } \\
\text { concentration at time, } t / q t\end{array}$ \\
40 & 0.284 & 0.254 \\
60 & 0.52 & 0.462 \\
70 & 0.684 & 0.642 \\
80 & 0.767 & 0.736 \\
90 & 0.856 & 0.825 \\
100 & 0.943 & 0.904 \\
110 & 1.048 & 1.005 \\
120 & 1.152 & 1.105 \\
& 1.257 & 1.206 \\
\hline
\end{tabular}

\section{Effect of initial concentration of manganese(II) and nickel(II)}

Sorption capacity of kaolinite and bentonite as a function of initial concentration of manganese(II) and nickel(II) ions in aqueous solution was determined by varying initial metal ion concentration from $40 \mathrm{mg} / \mathrm{L}$ to $200 \mathrm{mg} / \mathrm{L}$, volume of solution taken $100 \mathrm{~mL} 0.2 \mathrm{~g}$ of adsorbent used contact time 120 minutes $\mathrm{pH} 5$ maintained for manganese(II), pH:6 maintained for nickel(II) aqueous solution at room temperature $\left(30 \pm 1{ }^{0} \mathrm{C}\right)$. The metal ion adsorption per gram of adsorbent increased with the increase in initial metal ion concentration.

Table 9. Time profile and pseudo second order kinetics model for nickel(II)

\begin{tabular}{ccc}
\hline & \multicolumn{2}{c}{ adsorbents } \\
\hline \multirow{2}{*}{$\begin{array}{c}\text { Contact time } \\
\text { in min., } t\end{array}$} & kaolinite & Bentonite \\
\cline { 2 - 3 } & $\begin{array}{c}\text { Time/equilibrium } \\
\text { concentration at time, } t / q_{t}\end{array}$ & $\begin{array}{c}\text { Time/equilibrium } \\
\text { concentration at time, } t, t / q_{t}\end{array}$ \\
\hline 20 & 0.276 & 0.249 \\
40 & 0.496 & 0.463 \\
60 & 0.687 & 0.646 \\
80 & 0.882 & 0.841 \\
90 & 0.971 & 0.936 \\
100 & 1.061 & 1.028 \\
110 & 1.154 & 1.12 \\
120 & 1.247 & 1.212 \\
130 & 1.35 & 1.313 \\
140 & 1.454 & 1.414 \\
\hline
\end{tabular}

\section{Sorption isotherms}

The amount of adsorbent per unit mass of adsorbent $\left(\mathrm{q}_{\mathrm{e}}\right)$ can be related to equilibrium concentration of the metal ion using adsorption isotherms ${ }^{14}$. Data obtained from the effect of initial metal ion concentration were used to fit curves for different adsorption isotherms including Langmuir, Freundlich, Temkin and Frumkin adsorption isotherms ${ }^{15}$. The test revealed that the adsorption behaviour of manganese(II) and nickel(II) on to kaolinite and bentonite was best described by Langmuir and Freundlich adsorption isotherms. 
The linear plots of $c_{e} / q_{e} v s . c_{e}$ showed that the adsorption obeys Langmuir model for manganese(II) and nickel(II) on to kaolinite and bentonite and were shown in Figure $9 \& 10$.

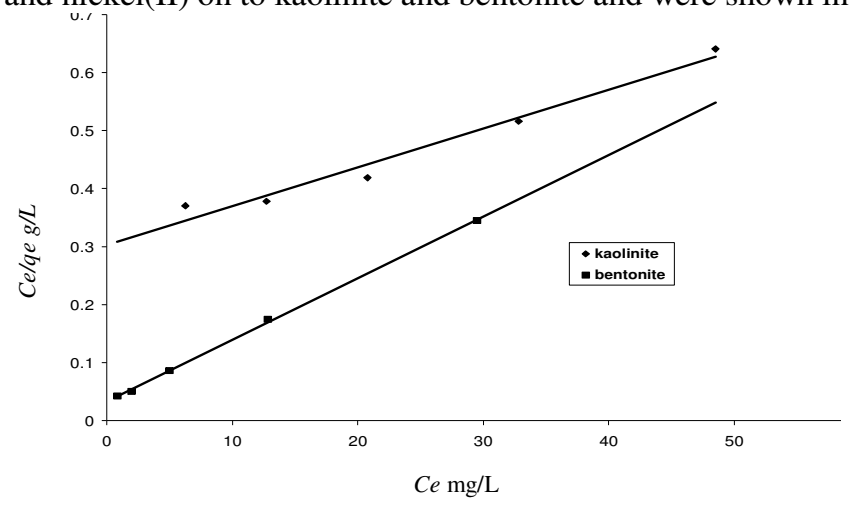

Figure 9. Langmuir adsorption isotherm for manganese(II)

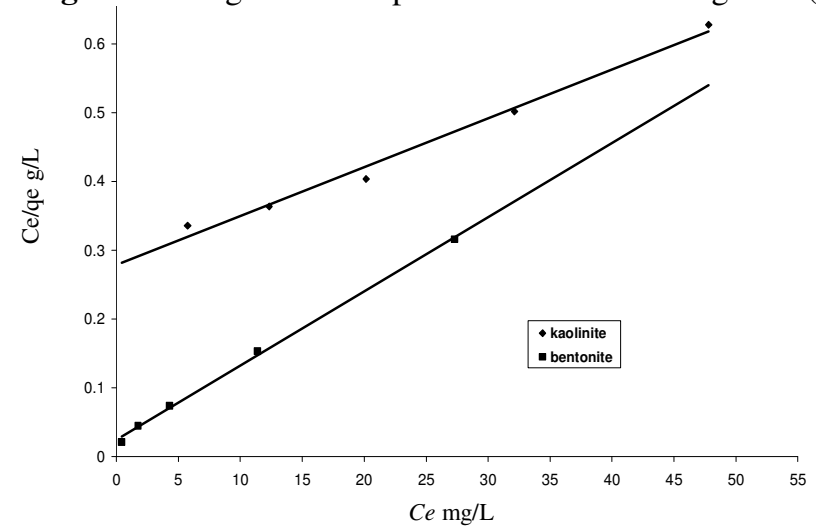

Figure 10. Langmuir adsorption isotherm for nickel(II)

$Q_{m}$ and $K_{L}$ were determined from Langmuir plots and were shown in Tables $10 \& 11$ along with regression coefficient $R^{2}$ values. The essential features of Langmuir adsorption isotherm can be expressed in terms of dimensionless constant called separation factor or equilibrium parameter $R_{L}$ which can be defined as follows.

$$
R_{L}=\frac{1}{\left(1+K_{L} C_{o}\right)}
$$

Where, $C_{0}$ is initial concentration of the adsorbate, $K_{L}$ - Langmuir constant. The significance of equation is that when $R_{L}>1$, the adsorption is unfavourable, when $0<R_{L}<1$ the adsorption is favourable and when $R_{L}=0$, the adsorption is irreversible. Values of $R_{L}$ obtained in the study were within the range of 0 and unity indicating that the adsorption of manganese(II) and nickel(II) on to kaolinite and bentonite is favourable.

Plots of $\log q_{e} v s . \log c_{e}$ are linear for manganese(II) and nickel(II) shown in Figure 11 $\& 12$. The straight line nature of plots indicates that the process followed were of Freundlich adsorption type. The $K_{f}$ and $n$ values for kaolinite and bentonite were calculated from the intercepts and slopes respectively and were shown in Table $10 \& 11$ along with the regression coefficient $\left(R^{2}\right)$ values. The values of $1<n<10$ showed favourable adsorption of manganese(II) and nickel(II) on to kaolinite and bentonite. 


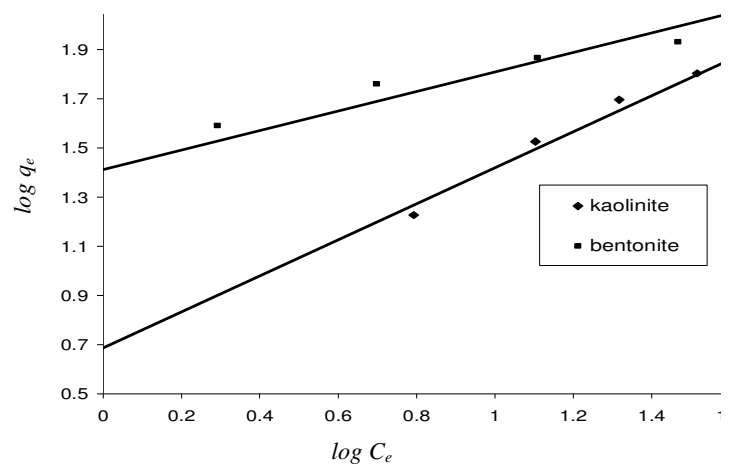

Figure 11. Freundlich adsorption isotherm for manganese(II)

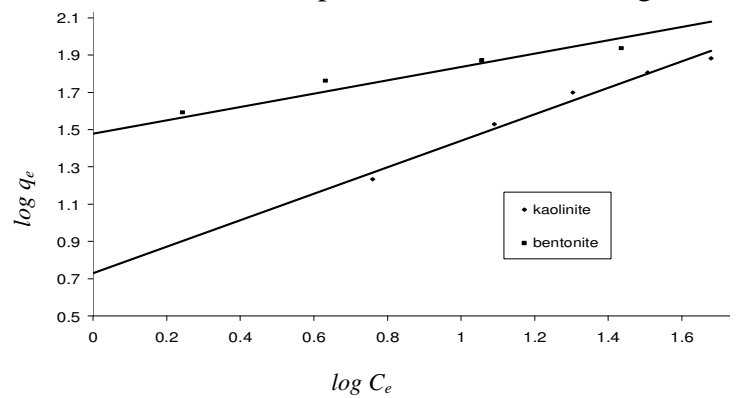

Figure 12. Freundlich adsorption isotherm for nickel(II)

Table 10. Freundlich and Langmuir constants for manganese(II)

\begin{tabular}{ccc}
\hline & \multicolumn{2}{c}{ Adsorbent } \\
\cline { 2 - 3 } & Kaolinite & Bentonite \\
\hline Freundlich & & \\
$K_{f}$ & 4.853 & 25.793 \\
$n$ & 1.365 & 2.518 \\
$R^{2}$ & 0.9763 & 0.92 \\
Longmuir & & \\
$Q_{m}$ & 149.25 & 94.34 \\
$K_{L}$ & 0.022 & 0.3233 \\
$R^{2}$ & 0.9711 & 0.9994 \\
\hline
\end{tabular}

Table 11. Freundlich and Langmuir constants for nickel(II)

\begin{tabular}{ccc}
\hline & \multicolumn{2}{c}{ Adsorbent } \\
\cline { 2 - 3 } & Kaolinite & Bentonite \\
\hline Freundlich & & \\
$K_{f}$ & 5.369 & 30.075 \\
$n$ & 1.4094 & 2.801 \\
$R^{2}$ & 0.9796 & 0.9633 \\
Langmuir & & \\
$Q_{m}$ & 140.84 & 92.59 \\
$K_{L}$ & 0.0254 & 0.44 \\
$R^{2}$ & 0.9873 & 0.998 \\
\hline
\end{tabular}


The shape of the isotherms on the two adsorbents is identical indicating a similar type of sorption process. It is expected that in the two adsorbents, the process of sorption is through ion-exchange. The kaolinite is hydrated aluminosilicates with 1:1 layer structure. The $\mathrm{H}^{+}$of hydroxyl groups are replaced by metals. This is the reason for adsorption of metals by kaolinite. Bentonite is also hydrated aluminosilicate with 2:1 layer structure. Here also the adsorption is same as that of in kaolinite. The adsorption of metal ions by bentonite is more than kaolinite It is because that bentonite has $700-800 \mathrm{~m}^{2} / \mathrm{g}$ specific surface area where as kaolinite has $7-30 \mathrm{~m}^{2} / \mathrm{g}$ surface area and bentonite has more cation exchange capacity $(70 \mathrm{~m}$ $\mathrm{Eq} / 100 \mathrm{~g})$ than kaolinite $(1-10 \mathrm{~m} \mathrm{Eq} / 100 \mathrm{~g})$.

\section{Conclusion}

From the present study it is clear that the low cost adsorbents kaolinite, bentonite are effective for the removal of heavy metals from aqueous solutions. Among the two adsorbents, bentonite is more effect than kaolinite. The sorption of two heavy metal ions on the adsorbents was affected by the parameters such as $\mathrm{pH}$, contact time, adsorbent dosage and initial metal ion concentration. The kinetic studies concluded that manganese(II) and nickel(II) removal followed pseudo second order rate equation. Equilibrium adsorption showed that adsorption of the metal ions followed both Langmuir and Freundlich models.

\section{References}

1. Hani H, Int J Environ Anal Chem., 1990, 39 (2), 197-208.

2. Kongsricharoem N and Polpraset C, Water Sci Technol., 1995, 31, 109-117.

3. Dean J G Bosqui F L and Lanouelte K H, Environ Sci Technol., 1972, 6, 518-522.

4. Fuerstean D W and Osseo Asare K, J Colloid Interface Sci., 1987, 118, 524.

5. Inoue K B, Yoshi neri SY and Egawa H, Sep Sci Technical., 1987, 22, 1349.

6. Mustafa S and Haq I, Environ Technol Lett., 1988, 9, 1379.

7. Priaswamy K and Namasivayam C, Waste Manag., 1995, 15, 63-68.

8. Volesky B and Holan Z R, Biotechnol Prog., 1995, 11, 235-250.

9. Sanchez G A, Ayuso A E and De Blass. J O, Soc Electronic J., 2002, 34(3), 469.

10. Glastone S, Textbook of Physical Chemistry $2^{\text {nd }}$ Edn., Macmillan India, 1981,1194.

11. Prasad M, Amritphale S S, Saxena S and Chabdra N, Ind Eng Chem Res., 2000, 39(8), 3034.

12. Wu F C, Tseng R L and Juang R S, Water Res., 2001, 35(3), 613-618.

13. Reddad Z, Gerenete C, Andres Y and Lecloirec P, Environ Sci Technol., 2002, 36, 2067-2073.

14. Arivoli S, Hema M, Karuppaiah M and Saravanan S, E-J Chem., 2008, 5(4), 820-831.

15. Odoemelam S A and Eddy N O, E-J Chem., 2009, 6(1), 213-222. 


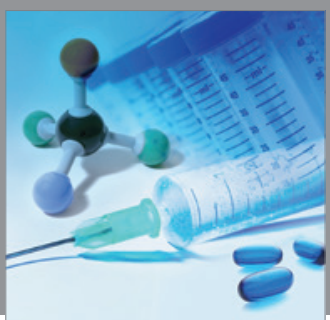

International Journal of

Medicinal Chemistry

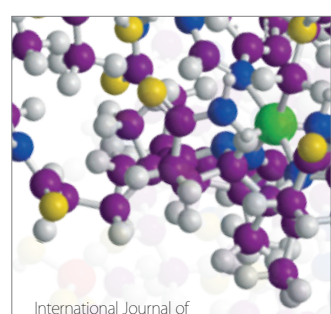

Carbohydrate Chemistry

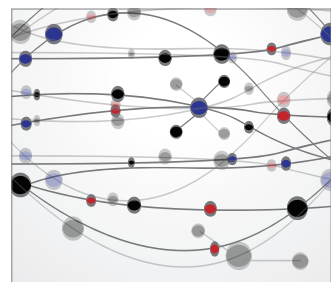

The Scientific World Journal
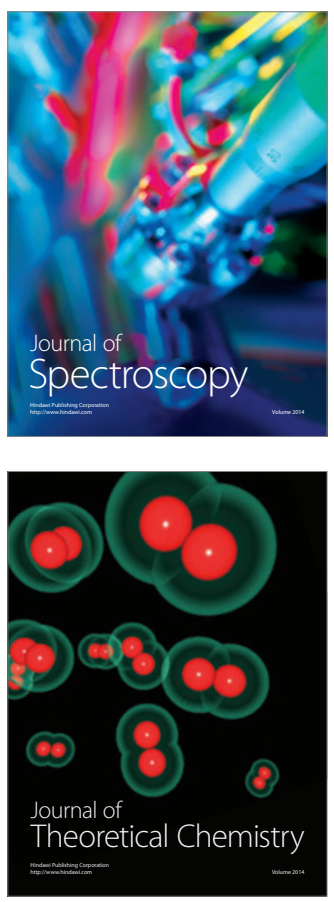
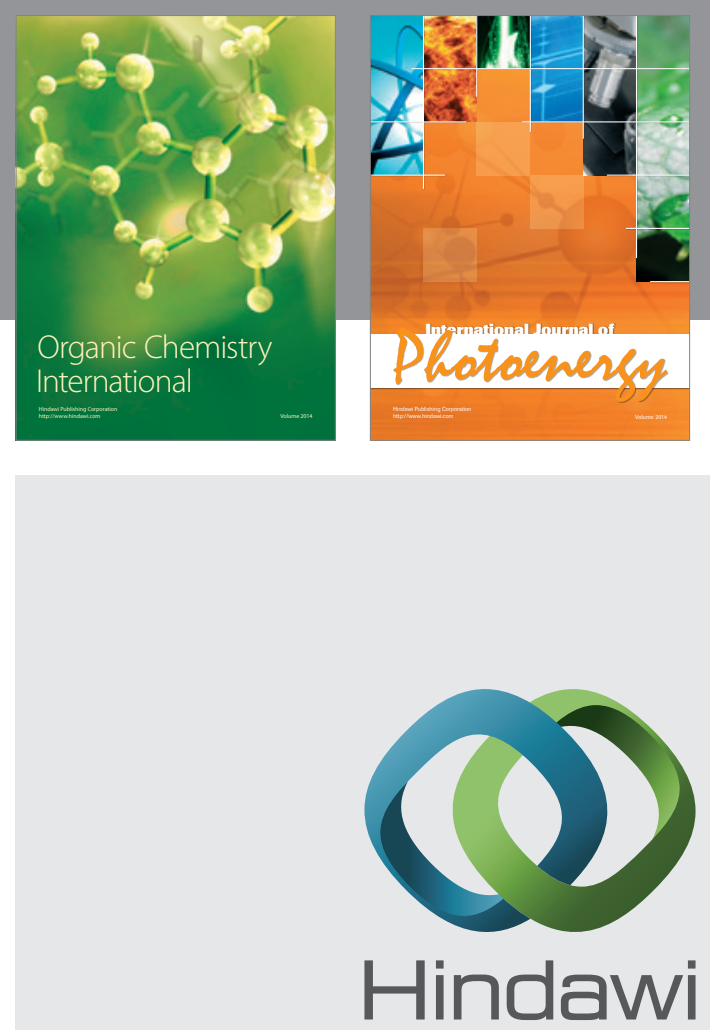

Submit your manuscripts at

http://www.hindawi.com
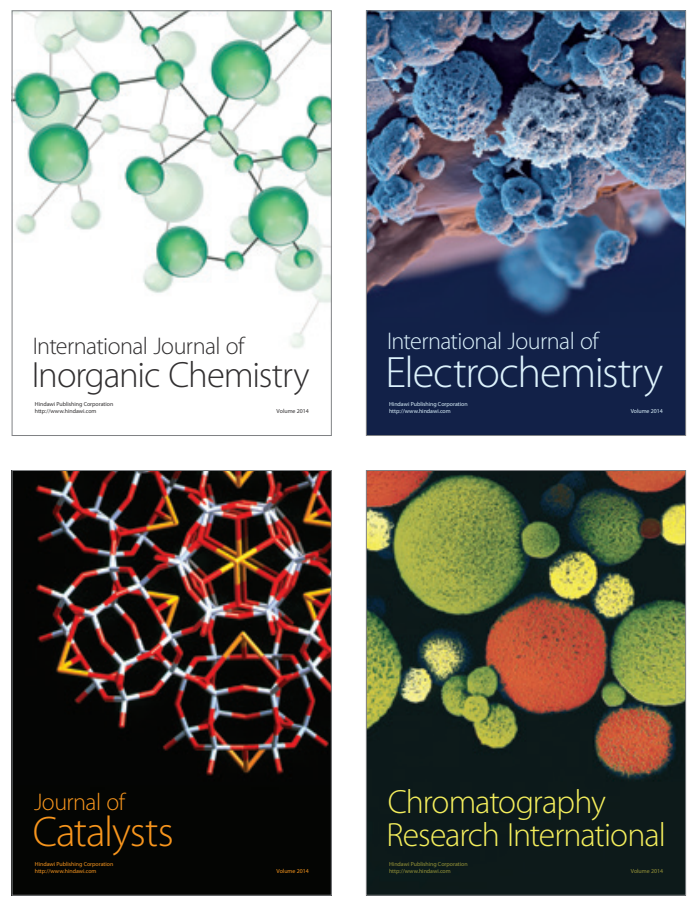
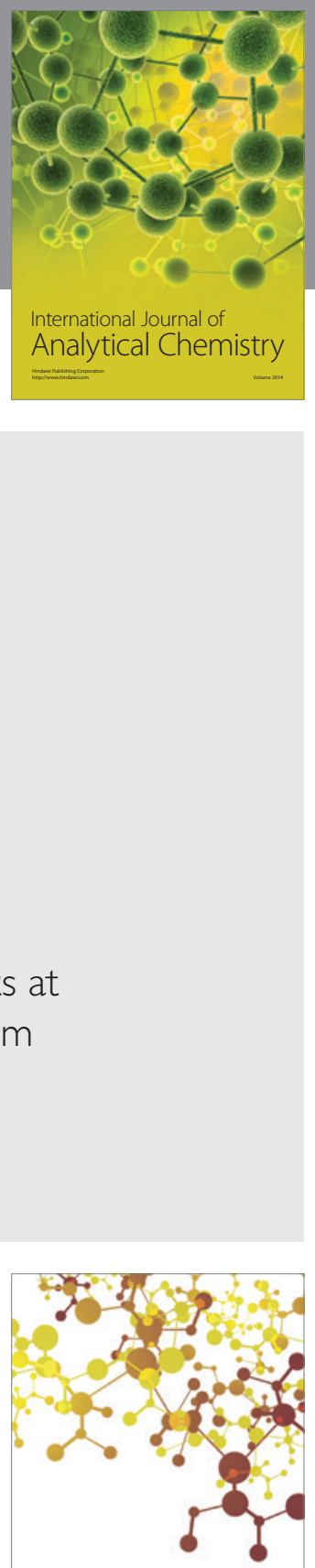

Journal of

Applied Chemistry
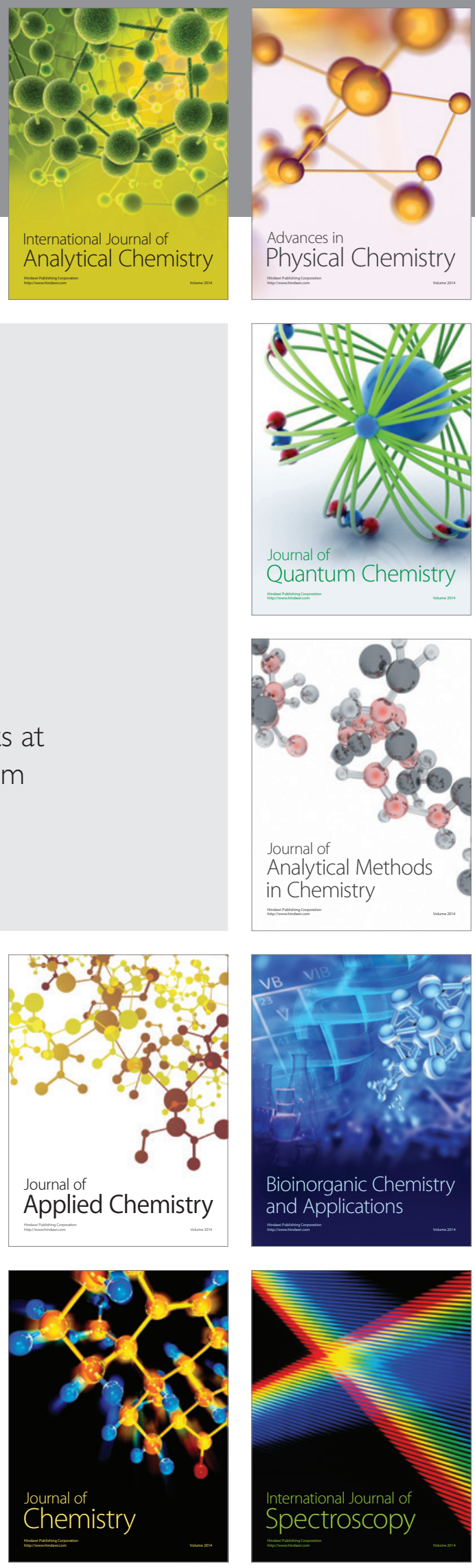